\title{
$16: 45475809-45522699$
}

National Cancer Institute

\section{Source}

National Cancer Institute. 16:45475809-45522699. NCI Thesaurus. Code C42419.

Physical location of GPT2_Gene 